\title{
DETERMINAN GROWTH FALTERING (GUNCANGAN PERTUMBUHAN) PADA BAYI UMUR 2-12 BULAN YANG LAHIR DENGAN BERAT BADAN NORMAL
}

\author{
Arie Nugroho \\ Jurusan Gizi Poltekkes Kemenkes Tanjungkarang \\ Email : arienugrohosgzmgz@gmail.com
}

\begin{abstract}
Growth Faltering Determinants among Infants Ages 2-12 Months who had Normal Birth Weight. Growth faltering is a very common occurrence in the age of the first year of life infants. Determinant factors are considered very powerful effect is infection and nutrition. Growth faltering in the first year of life infants would have a negative impact on the growth of both physical and mental life of a next toddler. Therefore it is important to investigate growth faltering determinants in solving the growth problems. This Observational study was conducted in a case control design in Langkapura district, Bandar Lampung. Cases were the subjects who had growth faltering, and controls were the subjects who had normal growth, both groups of 32 included subject in each group. The determinant variables investigated were non-colostrums feeding, nonexclusive breastfeeding, formula feeding, complementary food feeding, diarrhea and upper respiratory tract infections. Analysis was conducted by chi squere and Odds Ratio. Based on results chi squere, the determinants of growth faltering were: Non-exclusive breastfeeding $(\mathrm{OR}=$ 2,9; 95\% CI: 0,096-0,918; $\mathrm{p}=0,031$ ), and upper respiratory tract infections $\mathrm{OR}=3,4 ; 95 \% \mathrm{CI}$ : $1,17-9,80 ; p=0,04)$. Non-colostrums feeding, formula feeding, complementary food feeding and diarrhea were not the determinants. Conclucion and Suggestion: The main determinants of growth faltering among infants aged 2-12 months in Langkapura district were non-exclusive breastfeeding and upper respiratory tract infections. It is recommended to transfer knowledge about the importance of exclusive breastfeeding and upper respiratory tract infections prevention on infancy.
\end{abstract}

Keywords: Growth faltering, Non-exclusive breastfeeding, Upper respiratory tract infections.

\begin{abstract}
Abstrak: Determinan Growth Faltering (Guncangan Pertumbuhan) pada Bayi Umur 2-12 Bulan yang Lahir dengan Berat Badan Normal. Gangguan pertumbuhan merupakan kejadian yang sangat umum terjadi pada usia satu tahun pertama kehidupan balita. Faktor determinan yang dinilai sangat kuat pengaruhnya adalah infeksi dan gizi. Kejadian Growth faltering pada tahun pertama kehidupan balita akan berdampak negatif terhadap pertumbuhan baik fisik maupun mental pada kehidupan balita selanjutnya. Oleh karena itu perlu diketahui faktor determinan growth faltering agar dapat dilakukan pencegahan dan penanggulangan masalah tersebut. Penelitian ini termasuk penelitian observasional dengan disain penelitian kasus-kontrol, yang dilakukan di Kecamatan Langkapura, Kota Bandar Lampung. Subjek yang dijadikan kasus adalah bayi yang mengalami growth faltering, dan kontrol adalah bayi yang mengalami pertumbuhan normal. Jumlah subjek masing-masing kelompok kasus dan kontrol adalah 32 subjek. Variabel yang diamati meliputi tidak diberikannya kolostrum, ASI tidak eksklusif, susu formula, MP-ASI dini, riwayat diare, dan riwayat ISPA. Analisis data dilakukan dengan menggunakan uji chi square dan menilai Odds Ratio (OR). Hasil: Berdasarkan analisis chi square, determinan growth faltering adalah: Pemberian ASI tidak eksklusif ( $\mathrm{OR}=2,9 ; 95 \% \mathrm{CI}$ : $0,096-0,918 ; \mathrm{p}=0,031)$ dan ISPA $(\mathrm{OR}=$ 3,4; 95\% CI: $1,17-9,80 ; p=0,04)$. Variabel tidak diberikannya kolostrum, susu formula, MP-ASI dini dan kejadian diare bukan merupakan faktor determinan. Simpulan: Determinan growth faltering utama pada bayi umur 2-12 bulan di Kecamatan Langkapura adalah ASI tidak eksklusif dan kejadian ISPA. Disarankan untuk melakukan penyuluhan tentang pemberian ASI eksklusif dan pencegahan terhadap ISPA pada bayi.
\end{abstract}

Kata Kunci: Growth faltering, ASI tidak eksklusif, Kejadian ISPA.

Bayi yang sehat akan mengalami pertumbuhan dan perkembangan yang normal yaitu sesuai standar pertumbuhan fisik pada umumnya dan sesuai tahapan perkembangan sesuai usianya (Santrock J.W, 2007). Gangguan pada pertumbuhan ditunjukkan dengan rendahnya berat badan dan penurunan Z-Score menurut indeks BB/U (Kemenkes RI, 2011).

Gangguan pertumbuhan merupakan kejadian yang sangat umum terjadi pada usia satu 
tahun pertama kehidupan balita. Faktor determinan yang dinilai sangat kuat pengaruhnya adalah infeksi dan gizi. Kejadian growth faltering pada tahun pertama kehidupan balita akan berdampak negatif terhadap pertumbuhan baik fisik maupun mental pada kehidupan balita selanjutnya (Walker et al, 2003).

Apabila seorang anak mengalami pertumbuhan yang tidak sesuai dengan kurva pertumbuhannya, maka anak tersebut mengalami growth faltering. Menurut Shrimpton et al (2001), growth faltering ditunjukkan dengan penurunan Z-Score. Penelitian pada 39 negara di dunia menunjukkan growth faltering terjadi pada umur 4-12 bulan dengan penurunan Z-Score sebesar 1,5 SD BB/U di Asia, 1,25 SD BB/U di Amerika Latin dan penurunan 1,75 SD BB/U di Afrika.

Growth faltering terjadi pada masa awal kehidupan anak. Penelitian yang dilakukan oleh Kusharisupeni tahun 2002 menunjukkan bahwa growth faltering di Kabupaten Indramayu terjadi sejak dini terutama dimulai pada umur 2 bulan dan kelompok bayi yang paling terkena dampak growth faltering adalah kelompok bayi lahir normal. Penelitian yang dilakukan oleh Schmidt et al (2002) di 6 desa Jawa Barat menunjukkan bahwa growth faltering sering terjadi pada umur 6-7 bulan. Growth faltering berat badan yang diderita pada masa 9 bulan pertama kehidupan akan berdampak pada rendahnya IQ ketika umur mencapai 8 tahun. Rerata penurunan 1 Standar Deviasi akan menurunkan IQ sebesar 0,84 point ketika umur mencapai 8 tahun (Emond et al, 2007).

Ada berbagai macam faktor yang mempengaruhi growth faltering. Penelitian yang dilakukan oleh Salvador \& Lopez (2000) di Meksiko, pemberian ASI yang tidak eksklusif sebagai penyebab growth faltering pada 6 bulan pertama kehidupan seorang anak, sedangkan berdasarkan penelitian Prahesti (2002) di Semarang diperoleh bahwa variabel yang berhubungan dengan terjadinya growth faltering adalah praktek pemberian makanan/minuman prelaktal $(\mathrm{OR}=4,449)$. Penelitian yang dilakukan oleh Schmidt et al (2002) di Jawa Barat menunjukkan bahwa growh faltering pada umur 6-7 bulan lebih banyak terjadi karena faktor prenatal daripada post natal. Faktor prenatal yang bermakna meliputi berat badan lahir bayi yang rendah serta kurangnya penambahan berat badan ibu pada waktu hamil.

Berdasarkan Profil Kesehatan Provinsi Lampung tahun 2012 diperoleh data bahwa cakupan N/D pada tahun 2012 Kota Bandar Lampung diperoleh data N/D $=89,09 \%$, angka ini lebih tinggi dari angka Provinsi Lampung yaitu 74,51\%. Akan tetapi berdasarkan penelitian awal di Puskesmas Segalamider Kecamatan Langkapura diperoleh data N/D bulan januari $65,2 \%$ dimana target yang diharapkan $>75 \%$ (Dinkes Provinsi Lampung, 2012).

Tujuan penelitian ini adalah Diketahui faktor-faktor yang berhubungan dengan kejadian growth faltering pada bayi umur 2-12 bulan yang lahir dengan berat badan normal di Kecamatan Langkapura Kota Bandar Lampung.

\section{METODE PENELITIAN}

Penelitian ini termasuk penelitian observasional dengan disain penelitian kasuskontrol, yang dilakukan di Kecamatan Langkapura, Kota Bandar Lampung. Subjek yang dijadikan kasus adalah bayi yang mengalami growth faltering, dan kontrol adalah bayi yang mengalami pertumbuhan normal. Jumlah subjek masing-masing kelompok kasus dan kontrol adalah 32 subjek. Variabel yang diamati meliputi tidak diberikannya kolostrum, ASI tidak eksklusif, susu formula, MP-ASI dini, riwayat diare, dan riwayat ISPA.

Pengolahan data hasil penelitian yang telah dikumpulkan dilakukan menggunakan bantuan komputer. Analisis data menggunakan program komputer. Analisis dalam penelitian ini menggunakan uji chi squre dan menilai Odds Ratio (OR).

\section{HASIL}

\section{Univariat}

Berdasarkan hasil penelitian pada umumnya responden mendapatkan kolostrum yaitu sebanyak 48 subjek (75\%), pemberian ASI ekslusif yaitu 44 subjek $(68,8), 45$ subjek $(70,3 \%)$ mengkonsumsi susu formula. Selain itu 34 subjek $(53,1 \%)$ mendapat MP-ASI dini dan sebagian besar tidak mengalami riwayat diare yaitu 52 subjek $(81,2)$ akan tetapi mengalami riwayat ISPA sebesar 39 subjek (69\%). Selengkapnya dapat dilihat pada tabel 1. 
Tabel 1. Hasil Uji Univariat Variabel Penelitian

\begin{tabular}{|c|c|c|}
\hline Karakteristik & Jumlah & $\begin{array}{c}\text { Persentase } \\
(\%)\end{array}$ \\
\hline \multicolumn{3}{|l|}{ Pemberian kolostrum } \\
\hline $\mathrm{Ya}$ & 48 & 75 \\
\hline Tidak & 16 & 25 \\
\hline \multicolumn{3}{|l|}{$\begin{array}{l}\text { Pemberian ASI } \\
\text { ekslusif }\end{array}$} \\
\hline Ya & 44 & 68,8 \\
\hline Tidak & 20 & 31,2 \\
\hline \multicolumn{3}{|l|}{$\begin{array}{l}\text { Pemberian susu } \\
\text { formula }\end{array}$} \\
\hline Tidak & 45 & 70,3 \\
\hline Susu Formula & 19 & 29,7 \\
\hline \multicolumn{3}{|l|}{$\begin{array}{l}\text { Pemberian MP-ASI } \\
\text { dini }\end{array}$} \\
\hline Tidak & 30 & 46,9 \\
\hline MP-ASI dini & 34 & 53,1 \\
\hline Riwayat Diare & & \\
\hline $\begin{array}{l}\text { Tidak } \\
\text { Mengalami } \\
\text { diare }\end{array}$ & 52 & 81,2 \\
\hline $\begin{array}{l}\text { Mengalami } \\
\text { Diare }\end{array}$ & 12 & 18,8 \\
\hline $\begin{array}{l}\text { Riwayat ISPA } \\
\text { Tidak } \\
\text { mengalami } \\
\text { ISPA }\end{array}$ & 39 & 60,9 \\
\hline $\begin{array}{l}\text { Mengalami } \\
\text { ISPA }\end{array}$ & 25 & 39,1 \\
\hline
\end{tabular}

\section{Bivariat}

\section{a. Tidak diberikannya kolostrum}

Secara umum subjek yang diteliti mendapatkan kolostrum, yaitu sebanyak 48 orang dari 64 subjek, sedangkan sisanya 16 subjek tidak mendapatkan kolostrum. Subjek yang mengalami growth faltering dan tidak diberi kolostrum sebanyak 15,6\%, sedangkan subjek yang mengalami pertumbuhan normal sebanyak $34,4 \%$. Tabulasi silang tidak diberikannya kolostrum dengan gangguan pertumbuhan dapat dilihat pada tabel 2 .

Hasil analisis hubungan antara tidak diberikan kolostrum dengan gangguan pertumbuhan diperoleh bahwa ada sebanyak 27 $(84,4 \%)$ anak yang diberi kolostrum mengalami growth faltering, sedangkan anak yang tidak diberikan kolostrum yaitu sebanyak 15 anak $(15,6 \%)$ juga mengalami growth faltering. Hasil uji statistik diperoleh $p$-value 0,149 . Maka dapat disimpulkan tidak ada hubungan yang signifikan antara pemberian kolostrum dengan growth faltering.
Tabel 2.Tabulasi Silang Tidak Diberikannya Kolostrum dengan Gangguan Pertumbuhan

\begin{tabular}{|c|c|c|c|c|c|c|}
\hline \multirow[t]{2}{*}{ Variabel } & \multicolumn{2}{|c|}{$\begin{array}{l}\text { Pertumbuhan } \\
\text { Normal }\end{array}$} & \multicolumn{2}{|c|}{$\begin{array}{l}\text { Growth } \\
\text { faltering }\end{array}$} & \multirow[t]{2}{*}{$\begin{array}{c}\text { Nilai } \\
\mathrm{p}\end{array}$} & \multirow[t]{2}{*}{$\begin{array}{c}\text { CI 95\% } \\
\text { OR }\end{array}$} \\
\hline & $\mathrm{n}$ & $\%$ & $\mathrm{n}$ & $\%$ & & \\
\hline $\begin{array}{l}\text { Diberi } \\
\text { Kolostrum }\end{array}$ & 21 & 65,6 & 27 & 84,4 & 0,149 & $\begin{array}{c}\mathrm{OR}=0,35 \\
(0,016-\end{array}$ \\
\hline $\begin{array}{l}\text { Tidak } \\
\text { Diberi } \\
\text { Kolostrum }\end{array}$ & 11 & 34,4 & 5 & 15,6 & & $1,175)$ \\
\hline Jumlah & 32 & 100 & 32 & 100 & & \\
\hline
\end{tabular}

\section{b. Pemberian ASI Tidak Eksklusif}

Seluruh jumlah subjek yang mendapatkan ASI tidak eksklusif sebanyak 20 atau $31,2 \%$ subjek. Tabulasi silang pemberian ASI tidak eksklusif terhadap pertumbuhan dapat dilihat pada tabel 3 .

Hasil analisis hubungan antara Pemberian ASI ekslusif dengan gangguan pertumbuhan diperoleh bahwa ada sebanyak $26(81,2 \%)$ anak yang mendapat ASI ekslusif mengalami growth faltering, sedangkan anak yang tidak mendapat ASI ekslusif yaitu sebanyak 6 anak $(18,8 \%)$ juga mengalami growth faltering. Hasil uji statistik diperoleh $p$-value 0,031 . Artinya ada perbedaan proporsi growth faltering antara anak yang mendapat ASI ekslusif dengan anak yang mendapat ASI ekslusif (ada hubungan yang signifikan antara ASI ekslusif dengan growth faltering).

Tabel 3. Tabulasi Silang Pemberian ASI Tidak Eksklusif dan Pertumbuhan

\begin{tabular}{|c|c|c|c|c|c|c|}
\hline \multirow[t]{2}{*}{ Variabel } & \multicolumn{2}{|c|}{$\begin{array}{l}\text { Pertumbuhan } \\
\text { Normal }\end{array}$} & \multicolumn{2}{|c|}{$\begin{array}{c}\text { Growth } \\
\text { faltering }\end{array}$} & \multirow{2}{*}{$\begin{array}{c}\text { Nilai } \\
\mathrm{p}\end{array}$} & \multirow{2}{*}{$\begin{array}{c}\text { CI 95\% } \\
\text { OR }\end{array}$} \\
\hline & $\mathrm{n}$ & $\%$ & $\mathrm{n}$ & $\%$ & & \\
\hline \multirow{3}{*}{$\begin{array}{c}\text { Diberi } \\
\text { ASI } \\
\text { eksklusif } \\
\text { Diberi } \\
\text { ASI } \\
\text { tidak } \\
\text { eksklusif }\end{array}$} & & & & & \multirow{4}{*}{0,031} & \multirow{4}{*}{$\begin{array}{c}\mathrm{OR}=2,9 \\
(0,096- \\
0,918)\end{array}$} \\
\hline & 18 & 56,2 & 26 & 81,2 & & \\
\hline & 14 & 43,8 & 6 & 18,8 & & \\
\hline Jumlah & 32 & 100 & 32 & 100 & & \\
\hline
\end{tabular}

\section{c. Pemberian Susu Formula}

Seluruh jumlah subjek yang diberi susu formula sebanyak 19 atau 29,7\%. Sebagian besar subjek selain diberi susu formula juga masih disusui ASI oleh ibunya. Pemberian susu formula dilakukan dengan berbagai macam alasan diantaranya: ASI yang tidak keluar, atau tidak cukup untuk subjek, melanjutkan susu formula sejak dari Rumah Sakit atau bidan, dan alasan kepraktisan saat ditinggal pergi atau bekerja. Tabulasi silang pemberian susu formula dan 
pertumbuhan dapat dilihat pada tabel 4. Hasil analisis hubungan antara pemberian susu formula dengan gangguan pertumbuhan diperoleh bahwa ada sebanyak 19 (59,4\%) anak yang tidak diberi susu formula mengalami growth faltering, sedangkan anak yang diberikan susu formula yaitu sebanyak 13 anak (40,6\%) juga mengalami growth faltering.

Hasil uji statistik diperoleh $p$-value 0,055 . Maka dapat disimpulkan tidak ada perbedaan proporsi growth faltering antara anak yang mendapat susu formula dengan anak yang tidak mendapat susu formula (tidak ada hubungan yang signifikan antara pemberian susu formula dengan growth faltering).

Tabel 4. Tabulasi Silang Pemberian Susu Formula dan Pertumbuhan

\begin{tabular}{|c|c|c|c|c|c|c|}
\hline \multirow[t]{2}{*}{ Variabel } & \multicolumn{2}{|c|}{$\begin{array}{l}\text { Pertumbuhan } \\
\text { Normal }\end{array}$} & \multicolumn{2}{|c|}{$\begin{array}{l}\text { Growth } \\
\text { faltering }\end{array}$} & \multirow[t]{2}{*}{$\begin{array}{c}\text { Nilai } \\
\mathrm{p}\end{array}$} & \multirow{2}{*}{$\begin{array}{c}\text { CI } \\
95 \% \\
\text { OR }\end{array}$} \\
\hline & $\mathrm{n}$ & $\%$ & $\mathrm{n}$ & $\%$ & & \\
\hline Tidak & 26 & 81,2 & 19 & 59,4 & 0,055 & $\mathrm{OR}=$ \\
\hline Diberi & & & & & & 2,96 \\
\hline Susu & & & & & & $(0,95-$ \\
\hline Formula & & & & & & $9,21)$ \\
\hline Diberi & 6 & 18,8 & 13 & 40,6 & & \\
\hline Susu & & & & & & \\
\hline Formula & & & & & & \\
\hline Jumlah & 32 & 100 & 32 & 100 & & \\
\hline
\end{tabular}

\section{d. Pemberian Makanan Pendamping ASI Dini}

Dari seluruh jumlah subjek, yang mendapatkan MP-ASI dini sebanyak 34 atau 53,1 $\%$ subjek. Tabulasi Silang Pemberian MP-ASI Dini dan Pertumbuhan dapat dilihat pada tabel 5. Hasil analisis hubungan antara pemberian MPASI dini dengan gangguan pertumbuhan diperoleh bahwa ada sebanyak $20(62,5 \%)$ anak yang mendapat MP-ASI dini mengalami growth faltering, sedangkan anak yang tidak diberikan MP-ASI dini yaitu sebanyak 12 anak (37,5\%) juga mengalami growth faltering.

Hasil uji statistik diperoleh p-value 0,21. Maka dapat disimpulkan tidak ada perbedaan proporsi growth faltering antara anak yang mendapat MP-ASI dini dengan anak yang tidak mendapat MP-ASI dini (tidak ada hubungan yang signifikan antara pemberian MP-ASI dini dengan growth faltering).

Tabel 5. Tabulasi Silang Pemberian MP-ASI Dini dan Pertumbuhan

\begin{tabular}{|c|c|c|c|c|c|c|}
\hline \multirow[t]{2}{*}{ Variabel } & \multicolumn{2}{|c|}{$\begin{array}{l}\text { Pertumbuh } \\
\text { an Normal }\end{array}$} & \multicolumn{2}{|c|}{$\begin{array}{c}\text { Growth } \\
\text { faltering }\end{array}$} & \multirow[t]{2}{*}{$\begin{array}{l}\text { Nilai } \\
\mathrm{p}\end{array}$} & \multirow[t]{2}{*}{$\begin{array}{l}\text { CI 95\% } \\
\text { OR }\end{array}$} \\
\hline & $\mathrm{n}$ & $\%$ & $\mathrm{n}$ & $\%$ & & \\
\hline $\begin{array}{l}\text { Tdk MPASI } \\
\text { dini }\end{array}$ & 18 & 56,2 & 12 & 37,5 & 0,21 & $\begin{array}{l}\mathrm{OR}= \\
2,14\end{array}$ \\
\hline MPASI dini & 14 & 43,8 & 20 & 62,5 & & $(0,78-$ \\
\hline Jumlah & 32 & 100 & 32 & 100 & & $5,82)$ \\
\hline
\end{tabular}

\section{e. Riwayat Diare}

Pada saat penelitian, subjek yang mengalami diare sesuai kriteria ( $>3$ kali sehari) hanya $12(18,8 \%)$ subjek. Durasi diare adalah 2 hari dan frekuensi hanya satu kali dalam 2 minggu. Semua penderita diare terdapat pada kelompok yang mengalami pertumbuhan normal dan kelompok Growth Faltering. Tabulasi Silang kejadian diare dan pertumbuhan dapat dilihat pada tabel 6 .

Hasil analisis hubungan antara riwayat diare dengan gangguan pertumbuhan diperoleh bahwa ada sebanyak $5(15,6 \%)$ anak yang mengalami riwayat diare mengalami growth faltering, sedangkan anak yang tidak mengalami riwayat diare yaitu sebanyak 27 anak $(84,4 \%)$ juga mengalami growth faltering. Hasil uji statistik diperoleh $p$-value 0,749. Maka dapat disimpulkan tidak ada perbedaan proporsi growth faltering antara anak yang mengalami riwayat diare dengan anak yang tidak diare (tidak ada hubungan yang signifikan antara riwayat diare dengan growth faltering).

Tabel 6. Tabulasi Silang Riwayat Diare dan Pertumbuhan

\begin{tabular}{|c|c|c|c|c|c|c|}
\hline \multirow[t]{2}{*}{ Variabel } & \multicolumn{2}{|c|}{$\begin{array}{l}\text { Pertumbuhan } \\
\text { Normal }\end{array}$} & \multicolumn{2}{|c|}{$\begin{array}{l}\text { Growth } \\
\text { faltering }\end{array}$} & \multirow[t]{2}{*}{$\begin{array}{c}\text { Nilai } \\
\mathrm{p}\end{array}$} & \multirow{2}{*}{$\begin{array}{c}\text { CI } \\
95 \% \\
\text { OR }\end{array}$} \\
\hline & $\mathrm{n}$ & $\%$ & $\mathrm{n}$ & $\%$ & & \\
\hline Tidak & 25 & 78,1 & 27 & 84,4 & 0,749 & $\mathrm{OR}=$ \\
\hline Diare & & & & & & 0,6 \\
\hline $\begin{array}{l}\text { Mengalami } \\
\text { Riwayat } \\
\text { diare }\end{array}$ & 7 & 21,9 & 5 & 15,6 & & $\begin{array}{c}(0,18- \\
2,35)\end{array}$ \\
\hline Jumlah & 32 & 100 & 32 & 100 & & \\
\hline
\end{tabular}

\section{f. Riwayat Infeksi Saluran Pernapasan Atas}

Seluruh subjek yang mengalami ISPA dalam 2 minggu terakhir sebanyak 25 atau $39,1 \%$. Tabulasi silang Riwayat ISPA dan pertumbuhan dapat dilihat pada tabel 7. Hasil analisis hubungan antara riwayat ISPA dengan gangguan pertumbuhan diperoleh bahwa ada sebanyak $17(53,1 \%)$ anak yang mengalami riwayat ISPA mengalami growth faltering, sedangkan anak yang tidak mengalami ISPA yaitu sebanyak 15 anak (46,9\%) juga mengalami growth faltering.

Hasil uji statistik diperoleh p-value 0,04. Maka dapat disimpulkan ada perbedaan proporsi growth faltering antara anak yang mengalami riwayat ISPA dengan anak yang tidak mengalami ISPA (ada hubungan yang signifikan antara riwayat ISPA dengan growth faltering). 
Tabel 7. Tabulasi Silang ISPA dan Pertumbuhan

\begin{tabular}{|c|c|c|c|c|c|c|}
\hline \multirow[t]{2}{*}{ Variabel } & \multicolumn{2}{|c|}{$\begin{array}{c}\text { Pertumbuhan } \\
\text { Normal }\end{array}$} & \multicolumn{2}{|c|}{$\begin{array}{l}\text { Growth } \\
\text { faltering }\end{array}$} & \multirow[t]{2}{*}{$\begin{array}{c}\text { Nilai } \\
\mathrm{p}\end{array}$} & \multirow{2}{*}{$\begin{array}{c}\text { CI } \\
95 \% \\
\text { OR }\end{array}$} \\
\hline & $\mathrm{n}$ & $\%$ & $\mathrm{n}$ & $\%$ & & \\
\hline Tidak & 24 & 75 & 15 & 46,9 & 0,04 & $\mathrm{OR}=$ \\
\hline ISPA & & & & & & 3,4 \\
\hline Mengalami & 8 & 25 & 17 & 53,1 & & $1,17-$ \\
\hline $\begin{array}{c}\text { Riwayat } \\
\text { ISPA }\end{array}$ & & & & & & 9,80 \\
\hline Jumlah & 32 & 100 & 32 & 100 & & \\
\hline
\end{tabular}

\section{PEMBAHASAN}

\section{a. Tidak Diberikannya Kolostrum}

Tidak diberikannya kolostrum bukan merupakan faktor risiko terhadap kejadian growth faltering pada penelitian ini. Penelitian yang dilakukan oleh Prahesti (2001) menunjukkan hasil yang sama yaitu tidak ada hubungan yang secara statistik bermakna antara tidak diberikannnya kolostrum dengan terjadinya growth faltering $(\mathrm{OR}=2,67 ; \mathrm{p}=0,07)$.

Hasil ini berbeda dengan teori yang ada dimana kolostrum sangat penting diberikan pada bayi, terutama pada awal kehidupannya. Menurut Cox (2006), dalam 48 jam pertama kehidupannya, bayi tidak membutuhkan air susu terlalu banyak, hanya setengah sendok teh kolostrum saat pertama menyusu dan 1-2 sendok teh pada hari kedua. Cairan kental yang sangat sedikit seperti seulas cat itu akan melapisi saluran pencernaan bayi dan menghentikan masuknya bakteri ke dalam darah yang menimbulkan infeksi pada bayi.

Penelitian yang dilakukan oleh Edmond et al (2006), menunjukkan bahwa 16\% kematian bayi baru lahir seharusnya dapat diselamatkan dengan pemberian ASI pada hari pertama dan meningkat $22 \%$ jika menyusui dimulai 1 jam pertama setelah melahirkan. Wiryo (2007) menyatakan bahwa bayi yang tidak pernah mendapat kolostrum akan mudah terkena infeksi gastrointestinal dan diare karena bayi tidak mendapatkan senyawa-senyawa imunologikal yang terkandung dalam kolostrum.

\section{b. Pemberian ASI Tidak Eksklusif}

Ada hubungan pemberian ASI tidak eksklusif dengan kejadian growth faltering dianalisis dengan menggunakan uji chi squre. Hasilnya didapatkan $\mathrm{OR}=2,9 ; \quad 95 \% \quad \mathrm{CI}$ : $0,096-0,918 ; p=0,031$. Artinya pemberian ASI yang tidak eksklusif menjadi faktor risiko 2,90 kali terhadap kejadian growth faltering.

Selanjutnya dilakukan perhitungan Population attribute risk (PAR) untuk menghitung berapa proporsi growth faltering dalam populasi total dapat dicegah bila melakukan pemberian ASI eksklusif, dan hasilnya didapatkan $\mathrm{PAR}=0,56$. Dengan demikian dapat disimpulkan 56\% kasus growth faltering dapat dicegah dengan melakukan pemberian ASI eksklusif pada bayi umur 2-12 bulan di Kecamatan Langkapura.

Penelitian yang dilakukan oleh Salvador \& Lopez (2000), di Mexico menunjukkan bayi yang diberi ASI tidak eksklusif akan mengalami penambahan berat badan 240 gram lebih sedikit dalam 1 bulan dibanding bayi yang disusui dengan ASI eksklusif (p:0,03). Penelitian yang dilakukan oleh Alvarado (2005), di Colombia menunjukkan bayi yang diberi ASI tidak eksklusif akan mengalami penambahan berat badan 300 gram lebih sedikit dalam waktu 1 bulan dibanding bayi yang disusui ASI eksklusif ( $\mathrm{p}: 0,04)$. Pada penelitian ini bayi yang diberi ASI tidak eksklusif akan mengalami penambahan berat badan 267 gram lebih sedikit dalam waktu 1 bulan dibanding bayi yang disusi ASI ekslusif.

ASI berisi semua zat-zat gizi yang dibutuhkan oleh bayi dalam jumlah yang cukup. Kandungan energi ASI berkisar $65 \mathrm{mg} / 100 \mathrm{ml}$ ASI, adapun kandungan protein dalam ASI 0,9 $\mathrm{mg} / 100 \mathrm{ml}$ ASI. Kandungan protein dalam ASI memang lebih rendah dibandingkan dengan kadar protein susu formula $(1,6 \mathrm{mg} / 100 \mathrm{ml})$, namun kualitas protein ASI sangat tinggi dan mengandung asam-asam amino esensial yang sangat dibutuhkan oleh pencernaan bayi (Widjaja, 2004). Keistimewaan protein ASI adalah rasio protein whey dan kasein yang seimbang $(60: 40)$, dibanding dengan susu sapi (20 : 80). Hal ini menguntungkan bayi karena pengendapan dari protein whey lebih halus dibanding kasein sehingga protein whey lebih mudah cerna (Roesli, 2001). Jika bayi lapar atau haus, dia akan menyusu lebih sering atau lama, hal ini akan merangsang hormon prolaktin untuk memproduksi ASI lebih banyak, sehingga kebutuhan optimal bayi untuk pertumbuhan tercukupi (WHO, 2006).

Penelitian yang dilakukan oleh Suyatno (2000) di Demak, menunjukkan bayi yang disusui ASI eksklusif akan mengalami rerata kenaikan skor Z sebanyak 0,49 SD BB/U dalam waktu 4 bulan, atau rerata $0,12 \mathrm{SD} \mathrm{BB} / \mathrm{U}$ dalam 1 bulan, sedangkan bayi yang diberi makanan pendamping dini akan mengalami rerata kenaikan $0,24 \mathrm{SD} \mathrm{BB} / \mathrm{U}$ dalam waktu 4 bulan atau hanya mengalami rerata kenaikan $0,06 \mathrm{SD} \mathrm{BB} / \mathrm{U}$ dalam 1 bulan. Penelitian yang dilakukan oleh Salvador \& Lopez (2000) di Meksiko menunjukkan bayi yang diberi susu formula pada 6 bulan pertama justru akan mengalami penurunan skor $\mathrm{Z}$ 
sebanyak $-0,22 \mathrm{SD} \mathrm{BB} / \mathrm{U}$ pada saat lahir, menjadi $-1,00 \mathrm{SD} \mathrm{BB} / \mathrm{U}$ pada saat umur 6 bulan atau mengalami rerata penurunan $0,13 \mathrm{SD} \mathrm{BB} / \mathrm{U}$ dalam 1 bulan.

\section{c. Pemberian Susu Formula}

Pemberian susu formula bukan merupakan faktor risiko terhadap kejadian growth faltering. Hasil ini berbeda dengan teori yang ada dimana Bayi yang diberi susu formula akan beresiko mengalami growth faltering melalui 2 faktor yaitu tidak mendapatkan cukup energi dan zat gizi lain serta lebih mudah terkena infeksi (Walker W.A et al, 2003). Bayi tidak mendapat cukup energi, terutama pada bayi-bayi yang masih menyusui ASI dengan ditambah susu formula. Penelitian yang dilakukan oleh Giovanni M, et al (2004) di Italia menunjukkan bahwa pemberian susu formula akan menurunkan durasi menyusu ASI pada bayi. Ada beberapa faktor yang mempengaruhinya, diantaranya adalah karena bayi sudah merasa kenyang, produksi ASI yang kurang dan kesulitan adaptasi peralihan gaya menyusu dari menyusu botol kepada menyusu payudara ibu, atau biasa disebut dengan "bingung puting susu" (Cox, S. 2006).

Bayi yang diberi susu formula, akan lebih lama kenyang ( $3 \mathrm{jam})$, dibanding menyusu ASI (2 jam). Hal ini dikarenakan kandungan protein pada susu formula yang lebih tinggi kasein daripada whey (80:20), dimana kasein adalah protein yang sukar untuk dicerna oleh tubuh. Bayi yang sudah merasa kenyang, akan membuat jarak menyusu ASI ke payudara menjadi lebih lama. Akibatnya payudara akan kelebihan produksi ASI, secara otomatis rangsangan terhadap hormon prolaktin ke otak berkurang, sehingga sekresi ASI menjadi berkurang atau berhenti (Roesli, 2001).

Bayi yang terbiasa menyusu botol akan mengalami bingung puting pada saat menyusu payudara ibu, karena perbedaan gaya menyusu antara botol dan ASI. Pada saat menyusu ASI, seluruh bagian areola harus semua masuk ke dalam mulut bayi sehingga mulut bayi harus dalam keadaan terbuka lebar, selain itu bayi harus menyedot dengan kuat agar ASI dapat mengalir dengan lancar ke mulutnya. Pada saat menyusu botol, bayi hanya cukup menempelkan mulut pada ujung botol, dan hanya diperlukan sedikit usaha agar susu formula dapat mengalir ke dalam mulut. Bayi yang diberi ASI dengan ditambah susu formula akan kesulitan untuk beralih gaya menyusu pada saat menyusu ASI. Bayi akan cenderung menerapkan gaya menyusu botolnya pada saat menyusu ASI, akibatnya aliran ASI akan tidak lancar dan berkurang karena sedotan yang tidak maksimal, sementara bayi juga sudah terbiasa menyusu secara cepat. Hal ini membuat bayi kemungkinan hanya akan mendapatkan Foremilk, yaitu ASI yang keluar pada menit pertama, dengan komposisi lebih banyak mengandung air daripada lemak, sementara Hindmilk yaitu ASI yang keluar pada menit berikutnya, dengan komposisi tinggi lemak, tidak sempat diisap oleh bayi, padahal Hindmilk akan lebih dapat mengenyangkan dan memberi energi yang cukup untuk pertumbuhan bayi (WHO, 2006), akibatnya bayi tersebut akan kekurangan energi dari sumber ASI, di lain pihak, pemberian susu formula belum sesuai dengan kebutuhan bayi, sehingga bayi akan mengalami kekurangan zat-zat gizi untuk pertumbuhannya.

\section{d. Pemberian Makanan Pendamping ASI Dini}

MP-ASI dini bukan merupakan faktor risiko terhadap kejadian growth faltering. Penelitian yang dilakukan oleh Suyatno (2000) di Demak, menunjukkan bahwa MP-ASI dini tidak berpengaruh terhadap perubahan nilai skor $\mathrm{Z}$ BB/U, baik pada MP-ASI tradisional (RR: 0,161; 95\% CI; -0,44-0,11 p: 0,25), maupun MP-ASI Formula (RR: - 0,$161 ; 95 \%$ CI: 0,36-0,09 p: 0,233).

MP-ASI berisi lebih banyak karbohidrat, dibanding ASI. Walaupun membuat kenyang, tapi tidak mengandung cukup zat-zat gizi yang dibutuhkan untuk pertumbuhan, terutama lemak dan protein, selain itu pemberian MP-ASI berkaitan dengan fungsi organ pencernaan. Semakin muda usia, maka organ pencernaan secara anatomis dan fisiologis belum berfungsi sempurna dan hanya dapat menampung dan mencerna sedikit makanan (Giovannini $\mathrm{M}$ et al, 2004). Kecilnya daya cerna makanan, ditambah kandungan gizi yang tidak cukup, membuat bayi yang diberi MP-ASI pada usia yang lebih muda akan lebih rentan terhadap gangguan pertumbuhan.

\section{e. Riwayat Diare}

Riwayat diare bukan merupakan faktor risiko terhadap kejadian growth faltering pada bayi umur 2-12 bulan di Kecamatan Langkapura. Penelitian yang dilakukan oleh Kolstren PW, et al (1997) di Madura menunjukkan bahwa diare tidak berhubungan dengan pertumbuhan. Hal ini karena prevalensi diare yang kecil yaitu hanya $13 \%$ dari total sampel (1021), sehingga tidak berpengaruh pada pertumbuhannya. Pada penelitian ini penderita diare hanya $6,2 \%$ dan semua penderita diare mengalami pertumbuhan normal. Hal ini karena semua penderita diare 
mendapatkan ASI Eksklusif. Menurut Salvador \& Lopez (2000), bayi yang mengalami diare dan mendapatkan ASI Eksklusif akan mengalami penurunan berat badan 100 gram lebih sedikit daripada bayi yang diberi susu formula.

ASI mengandung zat anti infeksi yang dapat melindungi pertumbuhan bayi yaitu Immunoglobulin A (Ig A) yang cukup tinggi. Sekretori Ig A tidak diserap tetapi dapat melumpuhkan bakteri $E$ coli dan berbagai virus pada saluran pencernaan. Selain itu ASI juga mengandung zat kekebalan lain yaitu laktoferin dan lisosim. Laktoferin adalah sejenis protein yang merupakan komponen zat kekebalan dan mengikat zat besi dari saluran pencernaan. Lisosim adalah enzim yang melindungi bayi terhadap bakteri E.coli dan Salmonella, jumlahnya 300 kali lebih banyak dari pada susu sapi (Depkes RI, 2001).

ASI eksklusif

akan meningkatkan kekebalan tubuh dan asupan energi selama terjadinya infeksi, sehingga dapat lebih cepat memulihkan gangguan pertumbuhan. Oleh karena itu kejadian diare bukan merupakan faktor risiko terjadinya growth faltering pada bayi umur 2-12 bulan di Kecamatan Langkapura.

\section{f. Riwayat Infeksi Saluran Pernapasan Atas}

Pengaruh ISPA terhadap kejadian growth faltering dianalisis dengan menggunakan uji chi square. Hasilnya didapatkan nilai $\mathrm{OR}=3,4 ; 95 \%$ CI: $1,17-9,80 ; p=0,04$. Dengan demikian dapat disimpulkan ISPA akan meningkatkan kejadian growth faltering sebanyak 3,4 kali dibanding subjek yang tidak menderita ISPA.

Hasil perhitungan Population attribute risk (PAR) untuk menghitung berapa proporsi growth faltering dalam populasi total akan dapat dicegah dengan menghindari kejadian ISPA, hasilnya didapatkan $\mathrm{PAR}=0,60$. Dengan demikian dapat disimpulkan $60 \%$ kasus growth faltering dapat dicegah dengan menghindari kejadian ISPA pada bayi umur 2-12 bulan di Kecamatan Langkapura.

Menurut Walker W.A et al(2003), infeksi akan menyebabkan kebutuhan energi meningkat karena terjadinya demam, sementara infeksi juga menyebabkan anak kehilangan nafsu makan sehingga menurunkan jumlah energi yang masuk ke dalam tubuh. Menurut Shrimpton et al (2001) pada saat infeksi terjadi pelepasan interleukin 1 dan 2 oleh fagosit. Interleukin 1 akan menstimulasi proteolisis, dan neutrophilia. Interleukin 2 bereaksi pada hypothalamus dan menyebabkan panas serta menstimulasi peningkatan produksi adrenocorticotropik hormone $(\mathrm{ACTH})$ pada kelenjar hipofisis.
Demam akan meningkatkan basal metabolisme $12-13 \%$ untuk $1{ }^{0} \mathrm{C}$ peningkatan suhu. Sumber energi lain dibutuhkan karena simpanan karbohidrat tidak cukup untuk memenuhi peningkatan kebutuhan energi yang disebabkan oleh demam dan respon katabolik karena infeksi. Pada keadaan infeksi lemak bukan merupakan sumber energi yang efisien maka digunakan sumber protein dari otot untuk mensintesis glukosa pada hati. Defisiensi energi akan meningkat selama demam. Pada saat infeksi menjadi akut, respon katabolik mempunyai keseimbangan negatif pada nitrogen, natrium, dan seng serta kehilangan masa otot serta berat badan. Apabila konsumsi makanan yang diberikan tidak mencukupi maka penderita akan mengalami gangguan pertumbuhan.

Penelitian yang dilakukan oleh Kusumawati (2005), di Salatiga, menunjukkan bahwa ISPA mempunyai hubungan dengan laju pertumbuhan bayi. Bayi yang menderita ISPA akan mempunyai selisih laju pertumbuhan 0,330 $\mathrm{SD} \mathrm{BB} / \mathrm{U}$ lebih rendah dalam waktu 3 bulan, dibanding bayi yang tidak menderita ISPA. Pada penelitian ini subjek yang menderita ISPA akan menurun laju pertumbuhannya sebanyak 0,172 $\mathrm{SD}$ BB/U dalam waktu 1 bulan. Hal ini dapat dilihat dari persentase growth faltering yang lebih tinggi pada penderita ISPA yaitu sebanyak $53,1 \%$ dibanding $25,0 \%$ pada subjek yang tidak menderita ISPA.

\section{SIMPULAN}

Hasil penelitian menunjukkan bahwa determinan growth faltering adalah: Pemberian ASI tidak eksklusif $(\mathrm{OR}=2,9 ; 95 \% \quad \mathrm{CI}$ : $0,096-0,918 ; \mathrm{p}=0,031)$. dan ISPA $(\mathrm{OR}=3,4 ; 95 \%$ CI: $\quad 17-9,80 ; \quad p=0,04)$. Variabel tidak diberikannya kolostrum, susu formula, MP-ASI dini dan kejadian diare bukan merupakan faktor determinan Growth Faltering.

\section{SARAN}

Perlu ditingkatkan promosi pemberian ASI eksklusif, melalui penyuluhan sejak pemeriksaan kehamilan untuk mencegah kejadian growth faltering pada bayi umur 2-12 bulan, selain itu perlu melakukan pencegahan ISPA pada bayi, melalui usaha menghindarkan bayi dari kontak dengan orang lain yang sedang terkena ISPA, dan pemberian ASI eksklusif untuk menunjang kekebalan tubuhnya. 


\section{DAFTAR PUSTAKA}

Alvarado B.E, Zunzunegui M.V, Delisle H, Osorno J. 2005. Growth trajectories are influenced by breast-feeding and infant health in an afro-colombian community.

Cox, S. 2006. Breastfeeding with Confidence: Panduan untuk Belajar Menyusui dengan Percaya Diri. PT Elex Media Komputindo, Jakarta.

Departemen Kesehatan RI. 2001. Buku Panduan Manajemen Laktasi. Dirjen Kesehatan Masyarakat Direktorat Gizi Masyarakat. Jakarta.

Edmond, K.M, C. Zandoh, M.A Quigley, S.A. Etego, S.O. Agyei, B.R. Kirkwood. 2006. Delayed Breastfeeding Initiation Increase Risk of Neonatal Mortality. Pediatrics, 117: 380-386.

Giovannini M, Riva E, Banderali G, Scaglioni S, Veehof SH, Sala M, Radaelli G, Agostoni C. 2004. Feeding practices of infants through the first year of life in Italy. Acta Paediatr. 2004 Apr; 93(4): 492-7.

Kemenkes. 2011. SK Menkes 2010 tentang Standar Antropometri Penilaian Status Gizi Anak. Direktorat Jenderal Bina Gizi dan Kesehatan Ibu dan Anak. Direktorat Bina Gizi.

Kolstren PW, Kusin JA, Kardjati. Growth Faltering in Madura Indonesia: a Comparison with The NCHS Reference and Data from Kosongo, Zaire. Ann Trop Paediatr 1997 Sep; 16 (3): 233-242.

Kusharisupeni. 2002. Growth Faltering pada Bayi di Kabupaten Indramayu Jawa Barat. Makara, Kesehatan, Vol. 6, No. 1, Juni 2002.

Prahesti, Amy. 2001. Hubungan Pola Asuh Gizi dengan Gangguan Pertumbuhan (growth faltering) pada Anak usia 0-12 Bulan (Studi di Kecamatan Sumowono Kabupaten Semarang Tahun 2001).
Salvador Villalpando \& Mardya López-Alarcón. 2000. Growth Faltering Is Prevented by Breast-Feeding in Underprivileged Infants from Mexico City.

Santrock. J.W. 2007. Child Development Ed.11 McGraw-Hill Higher Education.

Schmidt, Marjanka, Siti Muslimatun, Clive E.West, Werner Schultink, Rainer Gross and Joseph G.A.J. Hautvast. Nutritional Status and Linear Growth of Growth of Indonesian Infants in West Java are Determined More By Prenatal Environment than by Postnatal Factors. J Nutr. 2002. 132: 2202-2207.

Shrimpton, Roger, Cesar G.Victora, Mercedes de Onis, Rosangela Costa Lima, Monika Blossner, and Graeme Clugston. 2001. Worldwide Timing of Growth Faltering: Implications for Nutritional Interventions. Pediatritcs; 107(5).

Suyatno. 2000. Pengaruh Pemberian Makanan Pendamping Asi (MP-ASI) Tradisional terhadap Kejadian ISPA, Diare dan Status Gizi pada 4 Bulan Pertama Kehidupannya. Thesis Tidak Dipublikasikan, Program Pasca Sarjana Universitas Gadjahmada, Yogyakarta.

Walker W.A, Watkins J.B, Duggan C. 2003. Nutrition in Pediatric. London: BC Decker Inc.

World Health Organization. 2006. Breastfeeding in The WHO Mulcentre Growth Reference Study. Acta Pædiatrica.

Widjaja, M.C. 2004. Gizi Tepat untuk Perkembangan Otak dan Kesehatan Balita. Jakarta: Kawan Pustaka.

Wiryo, H. 2007. The Effect of Early Solid Food Feeding and The Absence of Colostrum Feeding On Neonatal Mortality. FK Universitas Udayana. 